\title{
Proton conduction in hydronium solvate ionic liquids affected by ligand shape
}

\section{$\operatorname{AUTHOR}(\mathrm{S})$ :}

Kawata, Kio; Kitada, Atsushi; Tsuchida, Naoki; Saimura, Masayuki; Nagata, Takashi; Katahira, Masato; Fukami, Kazuhiro; Murase, Kuniaki

\section{CITATION:}

Kawata, Kio ...[et al]. Proton conduction in hydronium solvate ionic liquids affected by ligand shape. Physical Chemistry Chemical Physics 2021, 23(1): 449-456

\section{ISSUE DATE:}

2021-01-07

URL:

http://hdl.handle.net/2433/260845

\section{RIGHT:}

This is the accepted manuscript of the article, which has been published in final form at

https://doi.org/10.1039/d0cp05025c.; The full-text file will be made open to the public on 8 December 2021 in

accordance with publisher's 'Terms and Conditions for Self-Archiving'; この論文は出版社版でありません。引用の際に

は出版社版をご確認ざ利用ください。; This is not the published version. Please cite only the published version. 


\section{ARTICLE}

\section{Proton conduction in hydronium solvate ionic liquids affected by ligand shape}

Received 00th January 20xx, Accepted 00th January 20xx

DOI: $10.1039 / x 0 x x 00000 x$

\author{
Kio Kawata, ${ }^{a}$ Atsushi Kitada, ${ }^{* a}$ Naoki Tsuchida, ${ }^{a}$ Masayuki Saimura, ${ }^{b}$ Takashi Nagata, ${ }^{\text {b }}$ Masato \\ Katahira, ${ }^{\mathrm{b}}$ Kazuhiro Fukami ${ }^{\mathrm{a}}$ and Kuniaki Murase ${ }^{\mathrm{a}}$
}

\section{Introduction}

When two or more substances are mixed, the properties of the mixture can drastically change from those of pure substance. Moreover, even a slight structural change in one of the components can significantly affect the properties, which donate the designability of functions. The neutralization of Brønsted or Lewis acids and bases often results in ionization, e.g. dissociation, protonation, solvation, and complexation. Sometimes, the acid-base mixtures can be classified as ionic liquids (ILs), which are defined as salts that melt below $100{ }^{\circ} \mathrm{C}$. ILs show various characteristics, such as high ionic conductivity, high chemical and thermal stability, and solubility. Consequently, ILs have received significant attention as media for chemical, biochemical, and electrochemical systems. ${ }^{1-6}$

ILs can be classified into four types: solvate ILs, protic ILs, aprotic ILs, and inorganic ILs. ${ }^{7}$ We previously reported a hydronium $\left(\mathrm{H}_{3} \mathrm{O}^{+}\right)$ solvate IL $\left[\mathrm{H}_{3} \mathrm{O}^{+} \cdot 18 \mathrm{C} 6\right] \mathrm{Tf}_{2} \mathrm{~N} \quad\left(18 \mathrm{C} 6=18\right.$-crown-6; $\mathrm{Tf}_{2} \mathrm{~N}=$ bis[(trifluoromethyl)sulfonyl]amide, $\mathrm{Tf}=\mathrm{SO}_{2} \mathrm{CF}_{3}$ ) as the first example of a molten salt of $\left[\mathrm{H}_{3} \mathrm{O}^{+}\right.$. ligand $]$complex, ${ }^{8}$ while other groups had been reported solid state $\left[\mathrm{H}_{3} \mathrm{O}^{+}\right.$.ligand] complexes using common anions (e.g. $\mathrm{ClO}_{4}^{-}, \mathrm{SbF}_{6}^{-}, \mathrm{PF}_{6}^{-}, \mathrm{TfO}^{-}, \mathrm{BF}_{4}^{-}$, and $\left.\mathrm{FeCl}_{4}^{-}\right)^{9-12}$

\footnotetext{
a. Department of Materials Science and Engineering, Kyoto University, Sakyo-ku, Kyoto 606-8501, Japan.

E-mail: kitada.atsushi.3r@kyoto-u.ac.jp; Tel.: +81-75-753-5475; Fax: +81-75-7535463

b. Institute of Advanced Energy, Kyoto University, Gokasho, Uji, Kyoto 611-0011, Japan.

†Electronic Supplementary Information (ESI) available: The lists of ionic conductivities and viscosities for each hydronium solvate IL. Graphical representation of the equilibrium geometry of the most stable conformers of two $\left[\mathrm{H}_{3} \mathrm{O}^{+} \cdot \mathrm{Dh} 18 \mathrm{C} 6\right]$ cations and two $\left[\mathrm{H}_{3} \mathrm{O}^{+} \cdot \mathrm{B} 18 \mathrm{C} 6\right]$ cations (B3LYP/6-311+G** level). See DOI: $10.1039 / x 0 \times x 00000 x$
}

The hydronium solvate IL intersects the solvate and protic types of IL, where protic $\mathrm{H}_{3} \mathrm{O}^{+}$ion (i.e., solute) is solvated by $18 \mathrm{C} 6$ ligand (i.e., solvent) to form a $\left[\mathrm{H}_{3} \mathrm{O}^{+} \cdot 18 \mathrm{C} 6\right]$ complex cation (i.e., solvate) and $\mathrm{Tf}_{2} \mathrm{~N}^{-}$as the counter anion. Its strong Brønsted acidity among ILs (Hammett acidity $H_{0}=-4.4^{8}$ ) indicates that it may be used as an acid catalyst and in fuel cells. ${ }^{6,13-20}$

Moreover, the proton conduction of hydronium solvate ILs has been of special interest. Pulsed-field gradient spin echo nuclear magnetic resonance (PGSE-NMR) measurements revealed that protons of $\mathrm{H}_{3} \mathrm{O}^{+}$move faster than those of $18 \mathrm{C} 6$ ligands in $\left[\mathrm{H}_{3} \mathrm{O}^{+} \cdot 18 \mathrm{C} 6\right] \mathrm{Tf}_{2} \mathrm{~N} .{ }^{21}$ Among solvate ILs and protic ILs, ${ }^{22-25}$ this was the first observation of ligand exchange conduction without free neutral molecules. Further, unlike common solvate ILs and protic ILs, this cooperative proton relay is suppressed and $\mathrm{H}_{3} \mathrm{O}^{+}$come to move as slow as $18 \mathrm{C} 6$ ligands when diluted using equimolar $18 \mathrm{C} 6$ solvent. ${ }^{26}$ The proton conduction of the hydronium-based electrolytes would be interesting from the viewpoint of recently-proposed hydronium ion batteries $^{27,28}$ as well as fuel cells. ${ }^{6,13-15}$

In these studies, however, a key factor of the fast proton conduction has not been revealed. To understand the anomalous proton conduction, it is important to study analogous compounds with different ligands. Since $18 \mathrm{C} 6$ is a plausible ligand of $\mathrm{H}_{3} \mathrm{O}^{+}$and a good acceptor that binds $\mathrm{H}_{3} \mathrm{O}^{+}$cation selectively owing to its cavity size, ${ }^{-}$ 12,29 other candidate ligands are also cyclic or acyclic polyethers with six ether oxygens akin to $18 \mathrm{C} 6$.

In this work, three novel hydronium solvate ILs analogous to $\left[\mathrm{H}_{3} \mathrm{O}^{+} \cdot 18 \mathrm{C} 6\right] \mathrm{Tf}_{2} \mathrm{~N}$ are synthesized and the proton conduction of these hydronium solvate ILs are studied. A set of ${ }^{1} \mathrm{H}$ PGSE-NMR measurements was performed to determine the self-diffusion coefficients of $\mathrm{H}_{3} \mathrm{O}^{+}$and the ligands of the hydronium solvate ILs. The obtained results are also compared with density functional theory 
(DFT) calculations to reveal the distinguishable effect of ligand shape associated with cyclic or acyclic ligands on the proton conduction of hydronium solvate ILs.

\section{Experimental}

\section{Materials.}

Dicyclohexano-18-crown-6 (Dh18C6; Tokyo Chemical Industry Co., Ltd., $>98.0 \%$ purity), benzo-18-crown-6 (B18C6; Tokyo Chemical Industry Co., Ltd., $>96.0 \%$ purity), pentaethylene glycol dimethyl ether (G5; Nippon Nyukazai Co., 99.0\% purity), and bis[(trifluoromethyl)sulfonyl]imide $\left(\operatorname{HTf}_{2} \mathrm{~N}\right.$; Kanto Chemical, 99\% purity) were used without further purification. Ultrapure water was prepared using a Merck Milli-Q Reference A system.

\section{Synthesis of hydronium solvate ILs.}

We synthesized $\left[\mathrm{H}_{3} \mathrm{O}^{+} \cdot \mathrm{Dh} 18 \mathrm{C} 6\right] \mathrm{Tf}_{2} \mathrm{~N}$ and $\left[\mathrm{H}_{3} \mathrm{O}^{+} \cdot \mathrm{B} 18 \mathrm{C} 6\right] \mathrm{Tf}_{2} \mathrm{~N}$ in an Ar-filled glovebox using the methods reported in ref. 8 and 26 , respectively. On the other hand, $\left[\mathrm{H}_{3} \mathrm{O}^{+} \cdot \mathrm{G} 5\right] \mathrm{Tf}_{2} \mathrm{~N}$ was prepared in an Ar-filled glovebox as follows. Water was mixed with an equimolar amount of G5 in a septum-sealed vial at room temperature (RT), and then this mixture was added dropwise to $\mathrm{HTf}_{2} \mathrm{~N}$ at $-10{ }^{\circ} \mathrm{C}$.

\section{Characterization of hydronium solvate ILs.}

Melting points $\left(T_{\mathrm{m}}\right)$ and glass transition temperatures $\left(T_{\mathrm{g}}\right)$ were determined using a differential scanning calorimeter (DSC; Rigaku, DSC8231) at a heating rate of $5{ }^{\circ} \mathrm{C} \mathrm{min}^{-1}$. Proton nuclear magnetic resonance $\left({ }^{1} \mathrm{H} \mathrm{NMR}\right)$ spectra for $\left[\mathrm{H}_{3} \mathrm{O}^{+} \cdot \mathrm{Dh} 18 \mathrm{C} 6\right] \mathrm{Tf}_{2} \mathrm{~N}$ at $60{ }^{\circ} \mathrm{C}$, $\left[\mathrm{H}_{3} \mathrm{O}^{+} \cdot \mathrm{B} 18 \mathrm{C} 6\right] \mathrm{Tf} f_{2} \mathrm{~N}$ at $75{ }^{\circ} \mathrm{C}$, and $\left[\mathrm{H}_{3} \mathrm{O}^{+} \cdot \mathrm{G} 5\right] \mathrm{Tf}_{2} \mathrm{~N}$ at $25{ }^{\circ} \mathrm{C}$ were obtained at $600 \mathrm{MHz}$ using a JNM-ECA600 FT NMR spectrometer (JEOL Ltd.). The use of a double NMR tube, purchased from Shigemi Corp. (Catalog NO. SC-002), prevented the sample from mixing with the external standard. Traces of dimethyl sulfoxide- $d_{6}$ (Cambridge Isotope Laboratories, Inc.) were placed in the outer tube $(5.2 \mathrm{~mm} \phi)$ and compounds were added to the internal tube $(5.0 \mathrm{~mm} \phi)$. Thermal gravimetric analysis (TGA) was conducted for $\left[\mathrm{H}_{3} \mathrm{O}^{+} \cdot \mathrm{Dh} 18 \mathrm{C} 6\right] \mathrm{Tf}_{2} \mathrm{~N}$, $\left[\mathrm{H}_{3} \mathrm{O}^{+} \cdot \mathrm{B} 18 \mathrm{C} 6\right] \mathrm{Tf}_{2} \mathrm{~N}$, and $\left[\mathrm{H}_{3} \mathrm{O}^{+} \cdot \mathrm{G}_{5}\right] \mathrm{Tf}_{2} \mathrm{~N}$ at a heating rate of $5{ }^{\circ} \mathrm{C}$ $\mathrm{min}^{-1}$, using a TG-DTA8122 (Rigaku) instrument in a dry air atmosphere. Aluminum pans were used for the measurements. For each measurement, a $10 \mathrm{mg}$ sample was placed on the pan and $\mathrm{Al}_{2} \mathrm{O}_{3}$ was used as a standard.

Ionic conductivity $(\sigma)$ of the electrolyte was determined by electrochemical impedance spectroscopy for $\left[\mathrm{H}_{3} \mathrm{O}^{+} \cdot \mathrm{Dh} 18 \mathrm{C} 6\right] \mathrm{Tf}_{2} \mathrm{~N}$ from $50{ }^{\circ} \mathrm{C}$ to $90{ }^{\circ} \mathrm{C},\left[\mathrm{H}_{3} \mathrm{O}^{+} \cdot \mathrm{B} 18 \mathrm{C} 6\right] \mathrm{Tf}_{2} \mathrm{~N}$ from $60{ }^{\circ} \mathrm{C}$ to $85^{\circ} \mathrm{C}$, and $\left[\mathrm{H}_{3} \mathrm{O}^{+}\right.$. G5] Tf ${ }_{2} \mathrm{~N}$ from $5{ }^{\circ} \mathrm{C}$ to $45^{\circ} \mathrm{C}$. A Bio-Logic Science Instruments SAS, VSP-300, was used with stainless steel electrodes. The cell constant was calibrated with 0.1 and $1 \mathrm{~mol} \mathrm{dm}^{-3} \mathrm{KCl}$ aqueous solutions. The measurement was conducted in a thermostatic chamber (Espec Co., SU-222). Viscosity $(\eta)$ measurements were performed for each sample in the same temperature range as conductivity measurements using a viscometer (Kyoto Electronics Manufacturing Co., Ltd., EMS-1000). Using the measured values of weight and volume, densities $(\rho)$ for each compound were calculated.

Proton PGSE-NMR measurements were also performed for $\left[\mathrm{H}_{3} \mathrm{O}^{+} \cdot \mathrm{Dh} 18 \mathrm{C} 6\right] \mathrm{Tf}_{2} \mathrm{~N}\left(\right.$ at $70{ }^{\circ} \mathrm{C}$ ), $\left[\mathrm{H}_{3} \mathrm{O}^{+} \cdot \mathrm{B} 18 \mathrm{C} 6\right] \mathrm{Tf}_{2} \mathrm{~N}$ (at $75^{\circ} \mathrm{C}$ ), and $\left[\mathrm{H}_{3} \mathrm{O}^{+} \cdot \mathrm{G} 5\right] \mathrm{Tf}_{2} \mathrm{~N}$ (at $25^{\circ} \mathrm{C}$ ) by the same equipment used for NMR measurement. The self-diffusion coefficients of $\mathrm{H}_{3} \mathrm{O}^{+}$and ligands (Dh18C6, B18C6, and G5) in these compounds were measured using

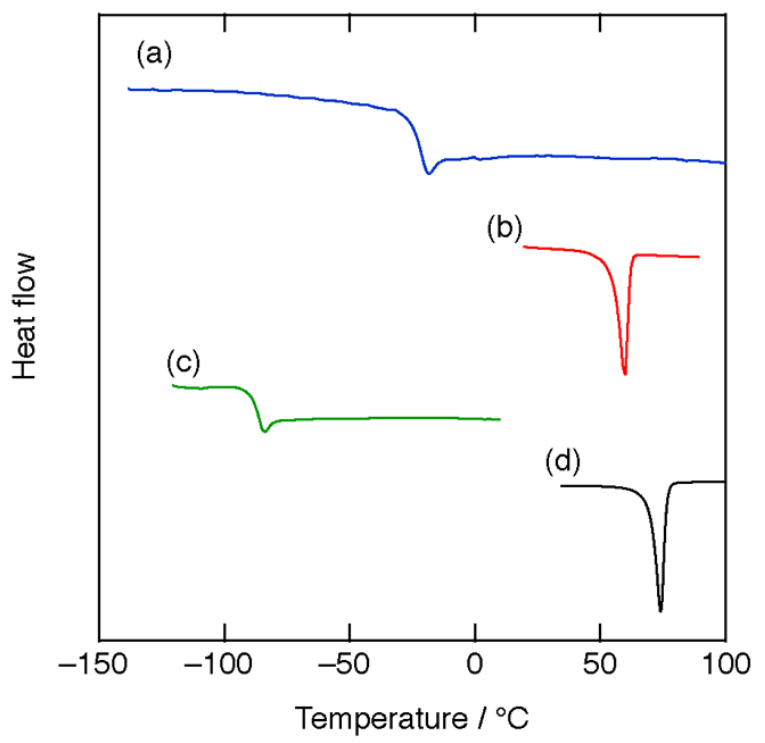

Fig. 1. DSC curves for (a) $\left[\mathrm{H}_{3} \mathrm{O}^{+} \cdot \operatorname{Dh} 18 \mathrm{C} 6\right] T f_{2} \mathrm{~N}$, (b) $\left[\mathrm{H}_{3} \mathrm{O}^{+} \cdot \mathrm{B} 18 \mathrm{C} 6\right] T \mathrm{~T}_{2} \mathrm{~N}$, (c) $\left[\mathrm{H}_{3} \mathrm{O}^{+} \cdot \mathrm{G} 5\right] T \mathrm{f}_{2} \mathrm{~N}$, and (d) $\left[\mathrm{H}_{3} \mathrm{O}^{+} \cdot 18 \mathrm{C} 6\right] \mathrm{Tf}_{2} \mathrm{~N}$ (ref. 8) at a heating rate of $5{ }^{\circ} \mathrm{C} \mathrm{min}^{-1}$.

Table 1 Physical properties of hydronium solvate ILs

\begin{tabular}{|c|c|c|c|c|}
\hline $\begin{array}{l}\text { Ideal composition and } \\
\text { formula weight }\left(\mathrm{g} \mathrm{mol}^{-1}\right)\end{array}$ & $\begin{array}{l}T_{\mathrm{m}} \text { or } T_{\mathrm{g}} \\
\quad\left({ }^{\circ} \mathrm{C}\right)\end{array}$ & $\begin{array}{c}\sigma \\
\left(\mathrm{mS} \mathrm{cm}^{-1}\right)\end{array}$ & $\begin{array}{c}\eta \\
(\mathrm{mPa} \mathrm{s})\end{array}$ & $\begin{array}{c}\rho \\
\left(\mathrm{g} \mathrm{cm}^{-3}\right)\end{array}$ \\
\hline $\begin{array}{c}{\left[\mathrm{H}_{3} \mathrm{O}^{+} \cdot \mathrm{Dh} 18 \mathrm{C} 6\right] \mathrm{Tf}_{2} \mathrm{~N}} \\
(671.67)\end{array}$ & $\begin{array}{c}T_{\mathrm{g}} \\
-24 \\
\end{array}$ & $\begin{array}{c}0.58 \\
\text { at } 70^{\circ} \mathrm{C}\end{array}$ & $\begin{array}{c}155.1 \\
\text { at } 70^{\circ} \mathrm{C}\end{array}$ & $\begin{array}{c}1.31 \\
\text { at RT }\end{array}$ \\
\hline $\begin{array}{c}{\left[\mathrm{H}_{3} \mathrm{O}^{+} \cdot \mathrm{B} 18 \mathrm{C} 6\right] \mathrm{Tf}_{2} \mathrm{~N}} \\
(611.53)\end{array}$ & $\begin{array}{c}T_{\mathrm{m}} \\
52-54\end{array}$ & $\begin{array}{c}0.85 \\
\text { at } 75^{\circ} \mathrm{C}\end{array}$ & $\begin{array}{c}106.8 \\
\text { at } 75^{\circ} \mathrm{C}\end{array}$ & $\begin{array}{c}1.33 \\
\text { at } 60^{\circ} \mathrm{C}\end{array}$ \\
\hline $\begin{array}{c}{\left[\mathrm{H}_{3} \mathrm{O}^{+} \cdot \mathrm{G} 5\right] \mathrm{Tf}_{2} \mathrm{~N}} \\
(565.51) \\
\end{array}$ & $\begin{array}{c}T_{\mathrm{g}} \\
-90 \\
\end{array}$ & $\begin{array}{c}2.22 \\
\text { at } 25^{\circ} \mathrm{C} \\
\end{array}$ & $\begin{array}{c}50.2 \\
\text { at } 25^{\circ} \mathrm{C} \\
\end{array}$ & $\begin{array}{c}1.45 \\
\text { at } 25^{\circ} \mathrm{C} \\
\end{array}$ \\
\hline $\begin{array}{c}{ }^{\mathrm{a}}\left[\mathrm{H}_{3} \mathrm{O}^{+} \cdot 18 \mathrm{C} 6\right] \mathrm{Tf}_{2} \mathrm{~N} \\
(563.48)\end{array}$ & $\begin{array}{c}T_{\mathrm{m}} \\
66-68 \\
\end{array}$ & $\begin{array}{c}2.36 \\
\text { at } 75^{\circ} \mathrm{C}\end{array}$ & $\begin{array}{c}42.9 \\
\text { at } 75^{\circ} \mathrm{C}\end{array}$ & $\begin{array}{c}1.32 \\
\text { at } 70^{\circ} \mathrm{C}\end{array}$ \\
\hline
\end{tabular}

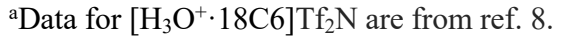


Table 2 Elemental analysis results for hydronium solvate ILs

\begin{tabular}{ccccccc}
\hline Compound & & $\mathrm{H}(\%)$ & $\mathrm{C}(\%)$ & $\mathrm{N}(\%)$ & $\mathrm{F}(\%)$ & $\mathrm{S}(\%)$ \\
\hline \multirow{2}{*}[\mathrm{H}_{3}\mathrm{O}^{+}\cdot\mathrm{Dh}18\mathrm{C}6]{$\mathrm{Tf}_{2} \mathrm{~N}$} & Experimental & 5.77 & 38.68 & 2.13 & 17.21 & 9.70 \\
& Calculated & 5.85 & 39.34 & 2.09 & 16.97 & 9.55 \\
\hline \multirow{2}{*}[\mathrm{H}_{3}\mathrm{O}^{+}\cdot\mathrm{B}18\mathrm{C}6]{$\mathrm{Tf}_{2} \mathrm{~N}$} & Experimental & 4.64 & 35.51 & 2.42 & 18.52 & 10.31 \\
& Calculated & 4.45 & 35.35 & 2.29 & 18.64 & 10.49 \\
\hline \multirow{2}{*}[\mathrm{H}_{3}\mathrm{O}^{+}\cdot\mathrm{G}5]{$\mathrm{Tf}_{2} \mathrm{~N}$} & Experimental & 5.33 & 29.52 & 2.45 & 20.13 & 11.29 \\
& Calculated & 5.17 & 29.74 & 2.48 & 20.16 & 11.34 \\
\hline
\end{tabular}

a simple Hahn spin echo sequence and analyzed using the Stejskal equation:

$$
\ln \left(I / I_{0}\right)=-D(\gamma g \delta)^{2}(\Delta-\delta / 3)
$$

where $I$ is the echo signal intensity, $I_{0}$ is the initial echo signal intensity, $D$ is the self-diffusion coefficient, $\gamma$ is the gyromagnetic ratio $\left(2.67515 \times 10^{8} \mathrm{rad} \mathrm{s}^{-1} \mathrm{~T}^{-1}\right.$ for $\left.{ }^{1} \mathrm{H}\right), g$ is the amplitude of the gradient pulses, $\delta$ is the duration of the gradient pulses, and $\Delta$ is the interval between the leading edges of the gradient pulses. ${ }^{30}$ The $g$ values used were in the range $20-270 \mathrm{mT} \mathrm{m}^{-1}$ for $\left[\mathrm{H}_{3} \mathrm{O}^{+} \cdot \mathrm{Dh} 18 \mathrm{C} 6\right] \mathrm{Tf}_{2} \mathrm{~N}$ and 20 $280 \mathrm{mT} \mathrm{m}^{-1}$ for $\left[\mathrm{H}_{3} \mathrm{O}^{+} \cdot \mathrm{B} 18 \mathrm{C} 6\right] \mathrm{Tf}_{2} \mathrm{~N}$ and $\left[\mathrm{H}_{3} \mathrm{O}^{+} \cdot \mathrm{G} 5\right] \mathrm{Tf}_{2} \mathrm{~N}$. The value of $\delta$ was $4 \mathrm{~ms}$ for $\left[\mathrm{H}_{3} \mathrm{O}^{+} \cdot \mathrm{Dh} 18 \mathrm{C} 6\right] \mathrm{Tf}_{2} \mathrm{~N}$ and $8 \mathrm{~ms}$ for $\left[\mathrm{H}_{3} \mathrm{O}^{+} \cdot \mathrm{B} 18 \mathrm{C} 6\right] \mathrm{Tf}_{2} \mathrm{~N}$ and $\left[\mathrm{H}_{3} \mathrm{O}^{+} \cdot \mathrm{G} 5\right] \mathrm{Tf}_{2} \mathrm{~N}$, and $\Delta$ was $100 \mathrm{~ms}$.

The Gaussian 16 program $^{31}$ was used for the ab initio molecular orbital calculations. The basis sets implemented in the Gaussian program were used. The geometry of $18 \mathrm{C} 6$, G5, Dh18C6, and B18C6 complexes with $\mathrm{H}_{3} \mathrm{O}^{+}$was fully optimized at the $\mathrm{B} 3 \mathrm{LYP} / 6-311+\mathrm{G}^{* *}$ level. Additionally, to investigate the<smiles>[CH]OCCO[C@H]1CCC(Cl)(Cl)C(Cl)C1OCCOCCOC1CCCCC1O</smiles><smiles>[CH]OCCOCCOCCOc1ccccc1O</smiles>
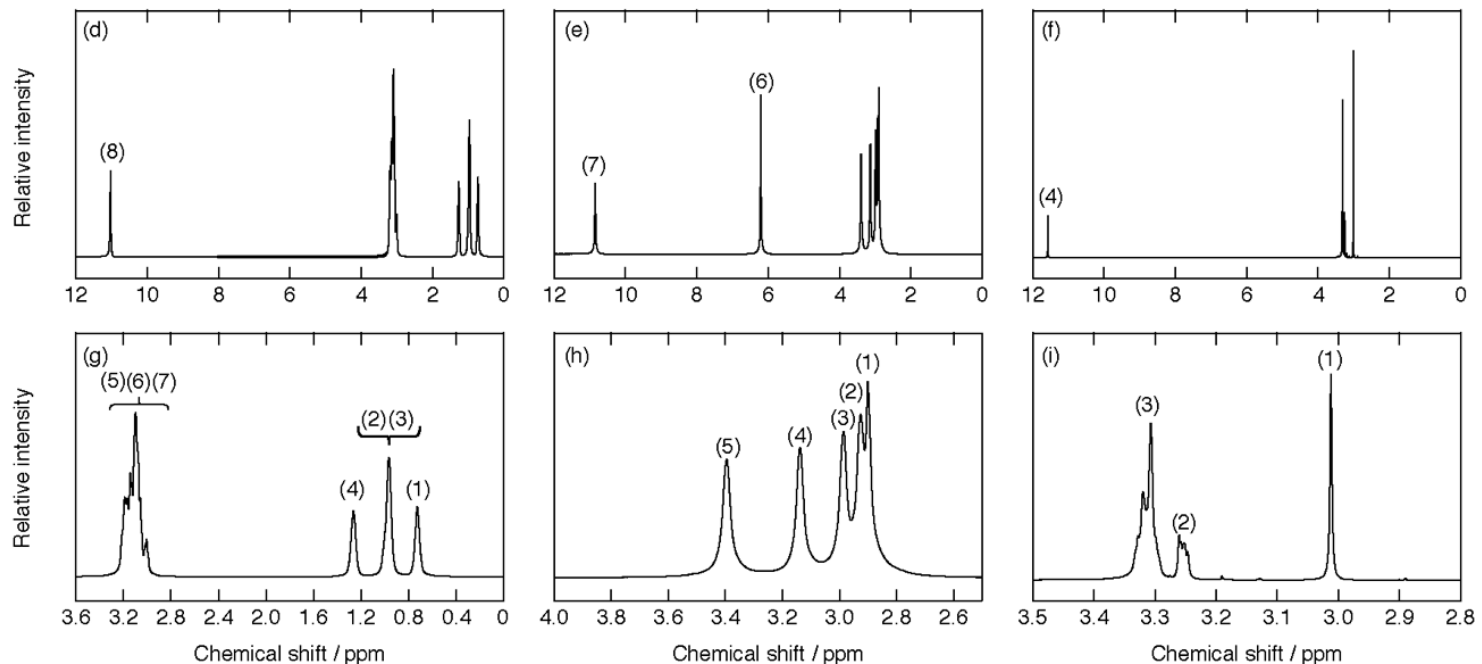

Fig. 2. (a-c) Schematic cation structure of (a) $\left[\mathrm{H}_{3} \mathrm{O}^{+} \cdot \mathrm{Dh} 18 \mathrm{C} 6\right]$, (b) $\left[\mathrm{H}_{3} \mathrm{O}^{+} \cdot \mathrm{B} 18 \mathrm{C} 6\right]$, and (c) $\left[\mathrm{H}_{3} \mathrm{O}^{+} \cdot \mathrm{G} 5\right]$; (d-f) ${ }^{1} \mathrm{H}$ NMR spectra; (g-i) enlarged plots for (d,g) $\left[\mathrm{H}_{3} \mathrm{O}^{+} \cdot \mathrm{Dh} 18 \mathrm{C} 6\right] \mathrm{Tf}_{2} \mathrm{~N}$ at $60{ }^{\circ} \mathrm{C}$, (e,h) $\left[\mathrm{H}_{3} \mathrm{O}^{+} \cdot \mathrm{B} 18 \mathrm{C} 6\right] \mathrm{Tf}_{2} \mathrm{~N}$ at $75{ }^{\circ} \mathrm{C}$, and $(\mathrm{f}, \mathrm{i})\left[\mathrm{H}_{3} \mathrm{O}^{+} \cdot \mathrm{G} 5\right] \mathrm{Tf}_{2} \mathrm{~N}$ at $25^{\circ} \mathrm{C}$. 


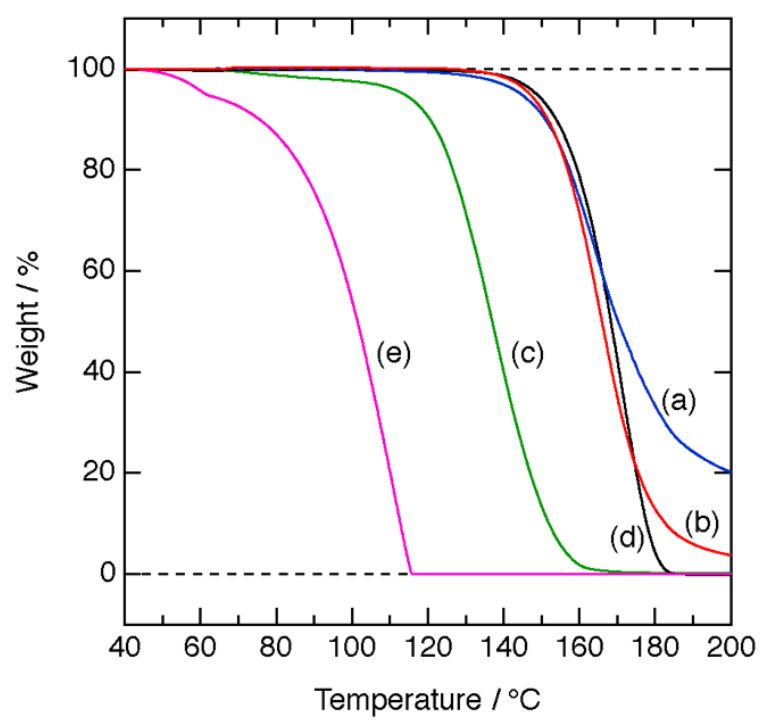

Fig. 3. TGA curves at a heating rate of $5{ }^{\circ} \mathrm{C} \mathrm{min}^{-1}$; (a) $\left[\mathrm{H}_{3} \mathrm{O}^{+} \cdot\right.$.Dh18C6]Tf $2 \mathrm{~N}$, (b) $\left[\mathrm{H}_{3} \mathrm{O}^{+} \cdot \mathrm{B} 18 \mathrm{C} 6\right] T \mathrm{Tf}_{2} \mathrm{~N}$, (c) $\left[\mathrm{H}_{3} \mathrm{O}^{+} \cdot \mathrm{G} 5\right] \mathrm{Tf}_{2} \mathrm{~N}$, (d) $\left[\mathrm{H}_{3} \mathrm{O}^{+} \cdot 18 \mathrm{C} 6\right] \mathrm{Tf}_{2} \mathrm{~N}$, and (e) $\mathrm{HTf}_{2} \mathrm{~N} \cdot \mathrm{H}_{2} \mathrm{O}$ (a-c: this work, e: ref. 8 , f: ref. 26).

show no physicochemical properties based on both pure ligands and precursor salts, satisfying the third criterion of solvate ILs. ${ }^{8,33}$

Table 2 shows the elemental analysis data for $\mathrm{H}, \mathrm{C}, \mathrm{N}, \mathrm{F}$, and $\mathrm{S}$ content of each mixture, which was performed at the center for Organic Elemental Microanalysis, Kyoto University. Oxygen atoms cannot be analyzed in principle of the elemental analysis. The data were consistent with the suggested formulations $\left[\mathrm{H}_{3} \mathrm{O}^{+} \cdot \mathrm{Dh} 18 \mathrm{C} 6\right] \mathrm{Tf}_{2} \mathrm{~N}$, $\left[\mathrm{H}_{3} \mathrm{O}^{+} \cdot \mathrm{B} 18 \mathrm{C} 6\right] \mathrm{Tf}_{2} \mathrm{~N}$, and $\left[\mathrm{H}_{3} \mathrm{O}^{+} \cdot \mathrm{G} 5\right] \mathrm{Tf}_{2} \mathrm{~N}$. The $\mathrm{H}_{2} \mathrm{O}$ contents, as analyzed by Karl-Fischer coulometric titration of $\left[\mathrm{H}_{3} \mathrm{O}^{+} \cdot \mathrm{Dh} 18 \mathrm{C} 6\right] \mathrm{Tf}_{2} \mathrm{~N}, \quad\left[\mathrm{H}_{3} \mathrm{O}^{+} \cdot \mathrm{B} 18 \mathrm{C} 6\right] \mathrm{Tf}_{2} \mathrm{~N}$, and $\left[\mathrm{H}_{3} \mathrm{O}^{+} \cdot \mathrm{G}_{5}\right] \mathrm{Tf}_{2} \mathrm{~N}$, were $2.61,3.03$, and $3.20 \mathrm{wt} \%$, which are in good agreement with the calculated values for each sample $\left(2.68 \mathrm{wt} \%\right.$ for $\left[\mathrm{H}_{3} \mathrm{O}^{+} \cdot \mathrm{Dh} 18 \mathrm{C} 6\right] \mathrm{Tf}_{2} \mathrm{~N}$, $2.94 \mathrm{wt} \%$ for $\left[\mathrm{H}_{3} \mathrm{O}^{+} \cdot \mathrm{B} 18 \mathrm{C} 6\right] \mathrm{Tf}_{2} \mathrm{~N}$, and $3.18 \mathrm{wt} \%$ for $\left.\left[\mathrm{H}_{3} \mathrm{O}^{+} \cdot \mathrm{G} 5\right] \mathrm{Tf}_{2} \mathrm{~N}\right)$. These quantitative analyses support that each complex had a ligand to $\mathrm{HTf}_{2} \mathrm{~N}$ to $\mathrm{H}_{2} \mathrm{O}$ molar ratio of $1: 1: 1$, suggesting that all the mixtures in this study form a solvate compound between an ion and a ligand in a certain stoichiometric ratio. This satisfies the first criterion of solvate ILs. $^{8,33}$

Figure 2 exhibits the schematic structure of the cations and the ${ }^{1} \mathrm{H}$ NMR spectra for the hydronium solvate ILs. The assignment of NMR signals for $\mathrm{H}_{3} \mathrm{O}^{+}$, Dh18C6, B18C6, and G5 are also displayed in each spectrum. The signals from $\mathrm{H}_{3} \mathrm{O}^{+}$in $\left[\mathrm{H}_{3} \mathrm{O}^{+} \cdot \mathrm{Dh} 18 \mathrm{C} 6\right] \mathrm{Tf}_{2} \mathrm{~N}$, $\left[\mathrm{H}_{3} \mathrm{O}^{+} \cdot \mathrm{B} 18 \mathrm{C} 6\right] \mathrm{Tf}_{2} \mathrm{~N}$, and $\left[\mathrm{H}_{3} \mathrm{O}^{+} \cdot \mathrm{G} 5\right] \mathrm{Tf}_{2} \mathrm{~N}$ appear at $11.03,10.86$, and 11.58 ppm, respectively. As reported previously, ${ }^{8}$ in $\left[\mathrm{H}_{3} \mathrm{O}^{+} \cdot 18 \mathrm{C} 6\right] \mathrm{Tf}_{2} \mathrm{~N}$, where unprotonated water is excluded and $\mathrm{H}_{3} \mathrm{O}^{+}$is solvated by $18 \mathrm{C} 6$ ligands, the chemical shift of the $\mathrm{H}_{3} \mathrm{O}^{+} \mathrm{NMR}$ signal is $10.85 \mathrm{ppm}$. As also discussed in our previous report, ${ }^{21}$ one ${ }^{1} \mathrm{H} \mathrm{NMR}$ singlet is observed at $8.18 \mathrm{ppm}$ in an equimolar mixture of $\mathrm{H}_{2} \mathrm{O}$ and $\mathrm{HTf}_{2} \mathrm{~N}\left(\mathrm{HTf}_{2} \mathrm{~N} \cdot \mathrm{H}_{2} \mathrm{O}\right)$, where its degree of dissociation is low and unprotonated $\mathrm{H}_{2} \mathrm{O}$ exists to some extent. Every $\mathrm{H}_{3} \mathrm{O}^{+}$signal in the compounds of this study is comparable to that of $\left[\mathrm{H}_{3} \mathrm{O}^{+} \cdot 18 \mathrm{C} 6\right] \mathrm{Tf}_{2} \mathrm{~N}$. Thus, these signals correspond to $\mathrm{H}_{3} \mathrm{O}^{+}$solvated by ligand, satisfying

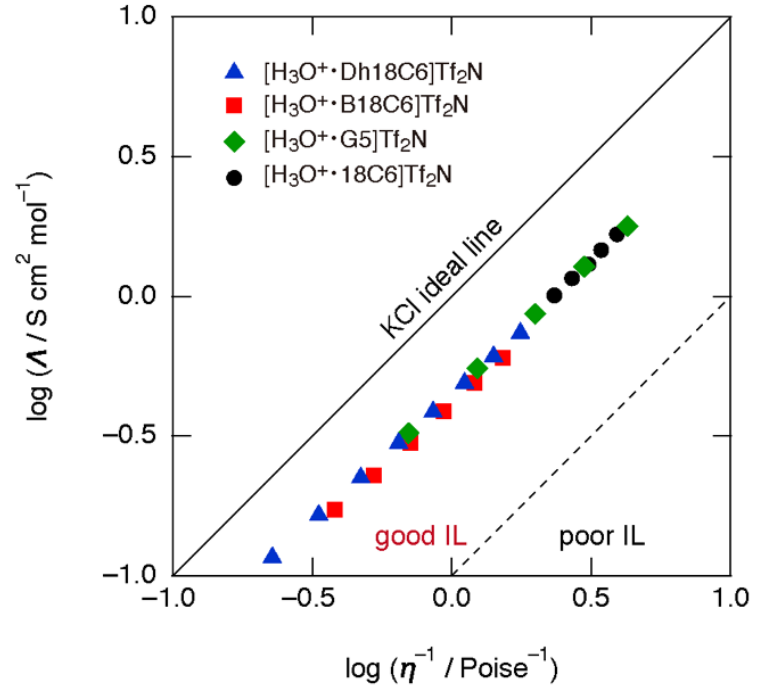

Fig. 4. Walden plots for $\left[\mathrm{H}_{3} \mathrm{O}^{+} \cdot \operatorname{Dh} 18 \mathrm{C} 6\right] T f_{2} \mathrm{~N},\left[\mathrm{H}_{3} \mathrm{O}^{+} \cdot \mathrm{B} 18 \mathrm{C} 6\right] T \mathrm{~T}_{2} \mathrm{~N}$, $\left[\mathrm{H}_{3} \mathrm{O}^{+} \cdot \mathrm{G} 5\right] T f_{2} \mathrm{~N}$, and $\left[\mathrm{H}_{3} \mathrm{O}^{+} \cdot 18 \mathrm{C} 6\right] T f_{2} \mathrm{~N}$ (ref. 8).

the second criterion of solvate ILs. ${ }^{8,33}$ Further, we can consider all NMR signals of each ligand to be from bound molecules, hence there are no physicochemical properties based on pure ligand. This supports the DSC results.

In TGA data (Fig. 3) with a heating rate of $5{ }^{\circ} \mathrm{C} \mathrm{min}^{-1}$, $\left[\mathrm{H}_{3} \mathrm{O}^{+} \cdot\right.$ Dh18C6]Tf $f_{2} \mathrm{~N},\left[\mathrm{H}_{3} \mathrm{O}^{+} \cdot \mathrm{B} 18 \mathrm{C} 6\right] \mathrm{Tf}_{2} \mathrm{~N}$, and $\left[\mathrm{H}_{3} \mathrm{O}^{+} \cdot \mathrm{G}_{5}\right] \mathrm{Tf}_{2} \mathrm{~N}$ start volatilizing at a much higher temperature than $\mathrm{HTf}_{2} \mathrm{~N} \cdot \mathrm{H}_{2} \mathrm{O}$ does, as is the case for $\left[\mathrm{H}_{3} \mathrm{O}^{+} \cdot 18 \mathrm{C} 6\right] \mathrm{Tf}_{2} \mathrm{~N} .{ }^{8}$ More precisely, $5 \mathrm{wt} \%$ loss is detected at around $150{ }^{\circ} \mathrm{C}$ for $\left[\mathrm{H}_{3} \mathrm{O}^{+} \cdot \mathrm{Dh} 18 \mathrm{C} 6\right] \mathrm{Tf}_{2} \mathrm{~N}$ and $\left[\mathrm{H}_{3} \mathrm{O}^{+} \cdot \mathrm{B} 18 \mathrm{C} 6\right] \mathrm{Tf} f_{2} \mathrm{~N}$, similar to the behavior of $\left[\mathrm{H}_{3} \mathrm{O}^{+} \cdot 18 \mathrm{C} 6\right] \mathrm{Tf}_{2} \mathrm{~N}$, while for $\left[\mathrm{H}_{3} \mathrm{O}^{+} \cdot \mathrm{G} 5\right] \mathrm{Tf}_{2} \mathrm{~N}$ it occurs at $110^{\circ} \mathrm{C}$. The vapor pressures of $\left[\mathrm{H}_{3} \mathrm{O}^{+} \cdot \mathrm{Dh} 18 \mathrm{C} 6\right] \mathrm{Tf}_{2} \mathrm{~N},\left[\mathrm{H}_{3} \mathrm{O}^{+} \cdot \mathrm{B} 18 \mathrm{C} 6\right] \mathrm{Tf}_{2} \mathrm{~N}$, and $\left[\mathrm{H}_{3} \mathrm{O}^{+} \cdot \mathrm{G} 5\right] \mathrm{Tf}_{2} \mathrm{~N}$ are negligible at temperatures lower than $100{ }^{\circ} \mathrm{C}$, satisfying the fifth criterion of solvate ILs. ${ }^{8,33}$

The DSC, ${ }^{1} \mathrm{H}$ NMR results, and elemental analysis suggest that compounds synthesized in this work consist of $\mathrm{H}_{3} \mathrm{O}^{+}$solvated by ligand (Dh18C6, B18C6, and G5) and $\mathrm{Tf}_{2} \mathrm{~N}^{-}$. Additionally, the TGA clarifies that $\left[\mathrm{H}_{3} \mathrm{O}^{+} \cdot \mathrm{Dh} 18 \mathrm{C} 6\right] \mathrm{Tf}_{2} \mathrm{~N}, \quad\left[\mathrm{H}_{3} \mathrm{O}^{+} \cdot \mathrm{B} 18 \mathrm{C} 6\right] \mathrm{Tf}_{2} \mathrm{~N}$, and $\left[\mathrm{H}_{3} \mathrm{O}^{+} \cdot \mathrm{G} 5\right] \mathrm{Tf}_{2} \mathrm{~N}$ have low volatility under $100{ }^{\circ} \mathrm{C}$. Therefore, $\left[\mathrm{H}_{3} \mathrm{O}^{+} \cdot \mathrm{Dh} 18 \mathrm{C} 6\right] \mathrm{Tf}_{2} \mathrm{~N},\left[\mathrm{H}_{3} \mathrm{O}^{+} \cdot \mathrm{B} 18 \mathrm{C} 6\right] \mathrm{Tf}_{2} \mathrm{~N}$, and $\left[\mathrm{H}_{3} \mathrm{O}^{+} \cdot \mathrm{G} 5\right] \mathrm{Tf} \mathrm{f}_{2} \mathrm{~N}$ are classified as solvate ILs according to the criteria, ${ }^{33}$ as well as the original hydronium solvate IL $\left[\mathrm{H}_{3} \mathrm{O}^{+} \cdot 18 \mathrm{C} 6\right] \mathrm{Tf}_{2} \mathrm{~N}{ }^{8}$

Physical properties (ionic conductivity $\sigma$, viscosity $\eta$, and density $\rho$ ) of $\left[\mathrm{H}_{3} \mathrm{O}^{+} \cdot \mathrm{Dh} 18 \mathrm{C} 6\right] \mathrm{Tf}_{2} \mathrm{~N},\left[\mathrm{H}_{3} \mathrm{O}^{+} \cdot \mathrm{B} 18 \mathrm{C} 6\right] \mathrm{Tf}_{2} \mathrm{~N},\left[\mathrm{H}_{3} \mathrm{O}^{+} \cdot \mathrm{G}^{2}\right] \mathrm{Tf}_{2} \mathrm{~N}$, and $\left[\mathrm{H}_{3} \mathrm{O}^{+} \cdot 18 \mathrm{C} 6\right] \mathrm{Tf}_{2} \mathrm{~N}$ are summarized in Table 1 . In addition, ionic

Table 3 The activation energy $\left(\mathrm{kJ} \mathrm{mol}^{-1}\right)$ for ionic conductivity and viscosity

\begin{tabular}{ccc}
\hline compound & ionic conductivity & viscosity \\
\hline$\left[\mathrm{H}_{3} \mathrm{O}^{+} \cdot \mathrm{Dh} 18 \mathrm{C} 6\right] \mathrm{Tf}_{2} \mathrm{~N}$ & 54.2 & 60.1 \\
{$\left[\mathrm{H}_{3} \mathrm{O}^{+} \cdot \mathrm{B} 18 \mathrm{C} 6\right] \mathrm{Tf}_{2} \mathrm{~N}$} & 49.9 & 55.0 \\
{$\left[\mathrm{H}_{3} \mathrm{O}^{+} \cdot \mathrm{G} 5\right] \mathrm{Tf}_{2} \mathrm{~N}$} & 31.4 & 33.2 \\
${ }^{\mathrm{a}}\left[\mathrm{H}_{3} \mathrm{O}^{+} \cdot 18 \mathrm{C} 6\right] \mathrm{Tf}_{2} \mathrm{~N}$ & 28.0 & 28.9 \\
\hline
\end{tabular}

${ }^{\mathrm{a}}$ Data for $\left[\mathrm{H}_{3} \mathrm{O}^{+} \cdot 18 \mathrm{C} 6\right] \mathrm{Tf}_{2} \mathrm{~N}$ are from ref. 8 . 
conductivities and viscosities for each hydronium solvate IL are listed in Tables S1, S2, and S3. A plot of molar conductivity $\left(\Lambda / \mathrm{S} \mathrm{cm}^{2} \mathrm{~mol}^{-}\right.$ $\left.{ }^{1}\right)$ vs. fluidity $\left(\eta^{-1} /\right.$ Poise $^{-1} ; 1$ Poise $\left.=0.1 \mathrm{~Pa} \mathrm{~s}\right)$, i.e., the Walden plot, is displayed in Fig. 4. The plot reveals that all compounds synthesized in this work are categorized as "good ILs" as well as $\left[\mathrm{H}_{3} \mathrm{O}^{+} \cdot 18 \mathrm{C} 6\right] \mathrm{Tf}_{2} \mathrm{~N}$ and common ILs. ${ }^{8,33-35}$ The activation energy for ionic conductivity and viscosity estimated from Arrhenius plots are listed in Table 3. Similar to $\left[\mathrm{H}_{3} \mathrm{O}^{+} \cdot 18 \mathrm{C} 6\right] \mathrm{Tf}_{2} \mathrm{~N},{ }^{8}$ the activation energy of all the compounds in this work for ionic conductivity is somewhat smaller than that for viscosity.

\section{Proton conduction of hydronium solvate ILs.}

The PGSE-NMR results in Fig. 5 show plots of echo signal attenuation based on the Stejskal equation for $\mathrm{H}_{3} \mathrm{O}^{+}$(black circles) and ligand (red circles) of $\left[\mathrm{H}_{3} \mathrm{O}^{+} \cdot \mathrm{Dh} 18 \mathrm{C} 6\right] \mathrm{Tf}_{2} \mathrm{~N}$ at $70{ }^{\circ} \mathrm{C}$, $\left[\mathrm{H}_{3} \mathrm{O}^{+} \cdot \mathrm{B} 18 \mathrm{C} 6\right] \mathrm{Tf}_{2} \mathrm{~N}$ at $75{ }^{\circ} \mathrm{C},\left[\mathrm{H}_{3} \mathrm{O}^{+} \cdot \mathrm{G} 5\right] \mathrm{Tf}_{2} \mathrm{~N}$ at $25{ }^{\circ} \mathrm{C}$, and $\left[\mathrm{H}_{3} \mathrm{O}^{+} \cdot 18 \mathrm{C} 6\right] \mathrm{Tf}_{2} \mathrm{~N}$ at $75{ }^{\circ} \mathrm{C} .{ }^{21} \mathrm{As}$ shown, the plots are linear.
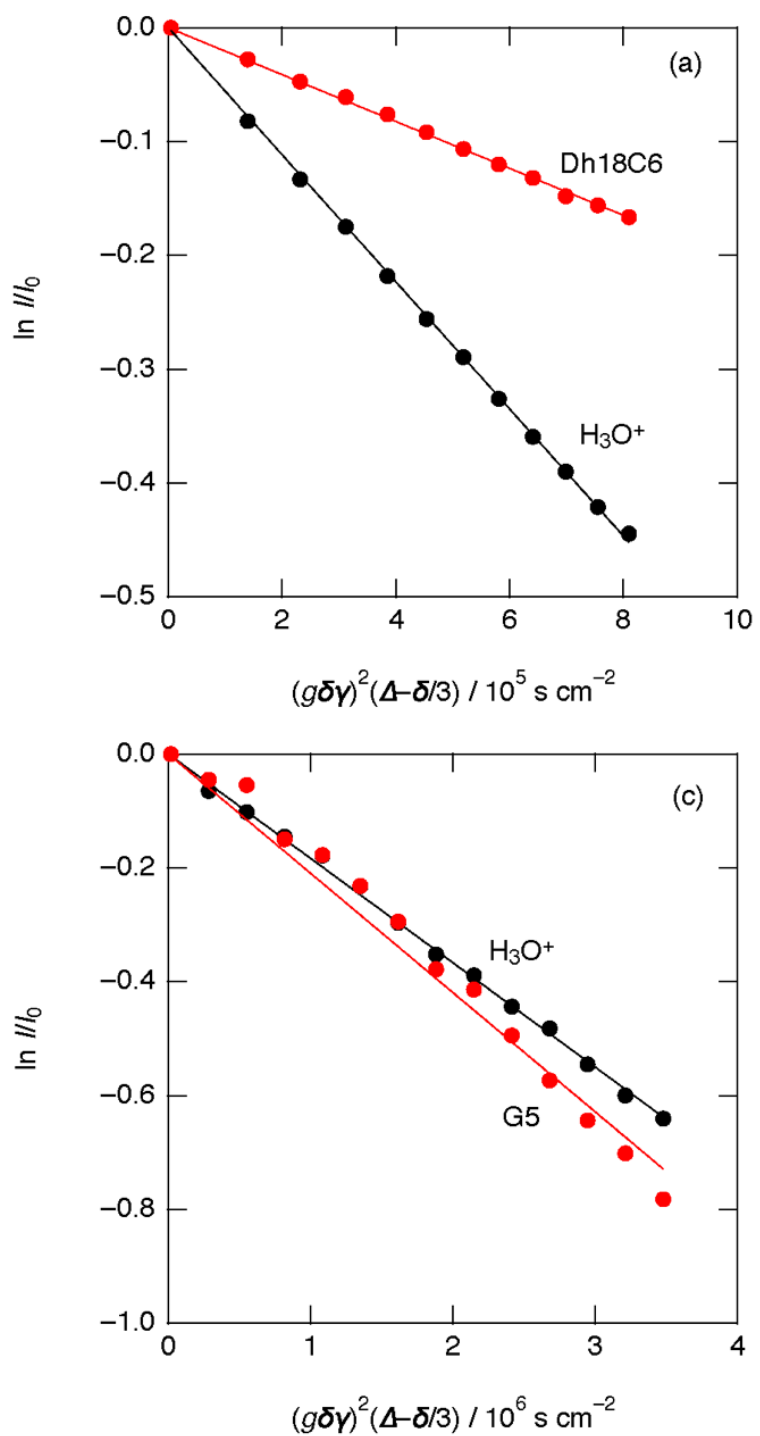

According to the Stejskal equation, the gradients of the fitted lines are proportional to the diffusion coefficients. Table 4 lists the estimated values of the self-diffusion coefficients for $\left[\mathrm{H}_{3} \mathrm{O}^{+} \cdot \mathrm{Dh} 18 \mathrm{C} 6\right] \mathrm{Tf}_{2} \mathrm{~N}$, $\left[\mathrm{H}_{3} \mathrm{O}^{+} \cdot \mathrm{B} 18 \mathrm{C} 6\right] \mathrm{Tf} f_{2} \mathrm{~N}, \quad\left[\mathrm{H}_{3} \mathrm{O}^{+} \cdot \mathrm{G} 5\right] \mathrm{Tf}_{2} \mathrm{~N}$, and previously reported $\left[\mathrm{H}_{3} \mathrm{O}^{+} \cdot 18 \mathrm{C} 6\right] \mathrm{Tf}_{2} \mathrm{~N}^{21}$ As in $\left[\mathrm{H}_{3} \mathrm{O}^{+} \cdot 18 \mathrm{C} 6\right] \mathrm{Tf}_{2} \mathrm{~N}$, the diffusion coefficients of $\mathrm{H}_{3} \mathrm{O}^{+}$are larger than those of the ligands (Dh18C6 and B18C6) in $\left[\mathrm{H}_{3} \mathrm{O}^{+} \cdot \mathrm{Dh} 18 \mathrm{C} 6\right] \mathrm{Tf}_{2} \mathrm{~N}$ and $\left[\mathrm{H}_{3} \mathrm{O}^{+} \cdot \mathrm{B} 18 \mathrm{C} 6\right] \mathrm{Tf} \mathrm{f}_{2} \mathrm{~N}$, respectively. For $\left[\mathrm{H}_{3} \mathrm{O}^{+} \cdot \mathrm{G} 5\right] \mathrm{Tf} f_{2} \mathrm{~N}$, in contrast, the coefficients of $\mathrm{H}_{3} \mathrm{O}^{+}$ and G5 are very similar, as in common Li-glyme based solvate ILs where the diffusion coefficient ratio of glyme to $\mathrm{Li}$ falls into the range 0.9-1.1. ${ }^{35}$ Consequently, protons of $\mathrm{H}_{3} \mathrm{O}^{+}$move faster than ligands in $\left[\mathrm{H}_{3} \mathrm{O}^{+} \cdot \mathrm{Dh} 18 \mathrm{C} 6\right] \mathrm{Tf} \mathrm{N}_{2} \mathrm{~N}$ and $\left[\mathrm{H}_{3} \mathrm{O}^{+} \cdot \mathrm{B} 18 \mathrm{C} 6\right] \mathrm{Tf}_{2} \mathrm{~N}$ as in the case of $\left[\mathrm{H}_{3} \mathrm{O}^{+} \cdot 18 \mathrm{C} 6\right] \mathrm{Tf}_{2} \mathrm{~N}$, while they move as fast as ligands in $\left[\mathrm{H}_{3} \mathrm{O}^{+} \cdot \mathrm{G} 5\right] \mathrm{Tf}_{2} \mathrm{~N}$. That is to say, the fast proton conduction is observed in all cyclic-ligand-based hydronium solvate ILs, while it was not observed in acyclic-ligand-based one. Note that in $\left[\mathrm{H}_{3} \mathrm{O}^{+} \cdot\right.$ Dh18C6]Tf $f_{2} \mathrm{~N}$ the $\mathrm{H}_{2} \mathrm{O}$ content analyzed by Karl-Fischer titration $(2.61 \mathrm{wt} \%)$ is somewhat smaller than the calculated value (2.68 $\mathrm{wt} \%)$ as above. Therefore, it is not the case that a little extra
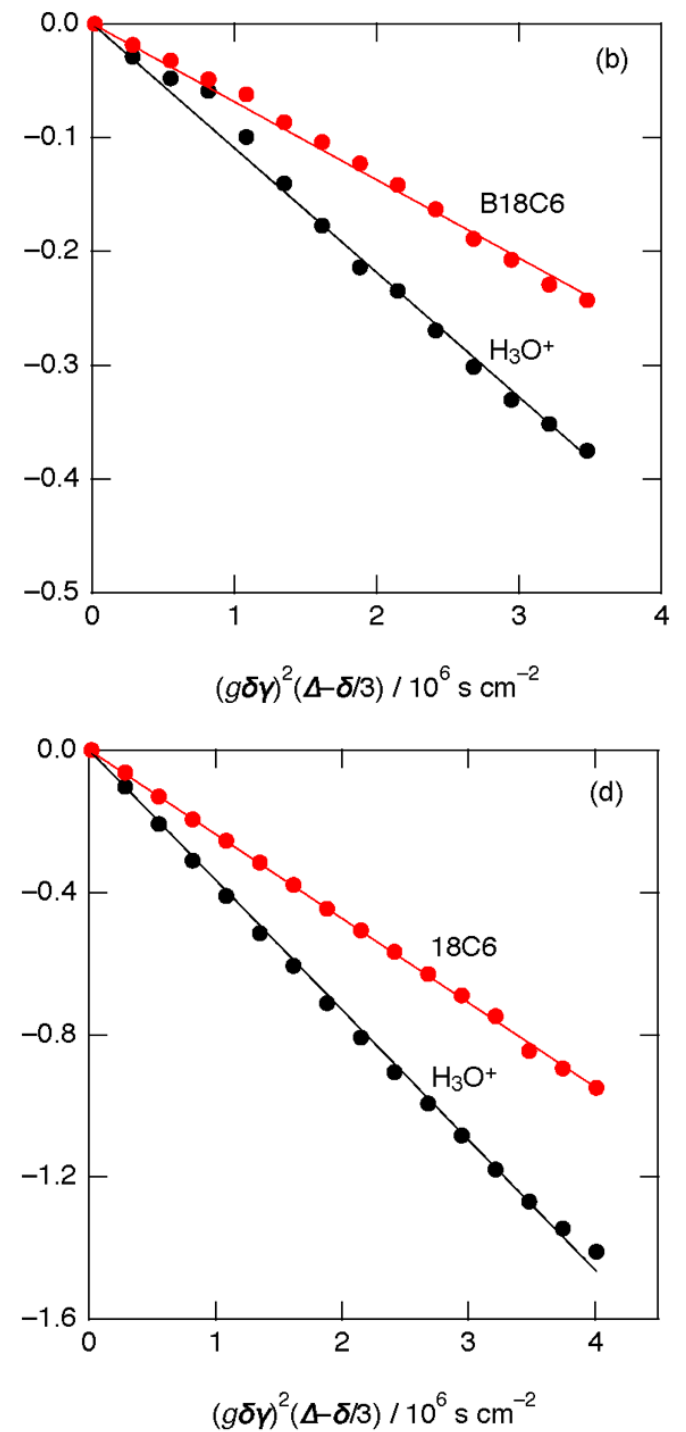

Fig. 5. Plots and best-fit lines of echo signal attenuation based on the Stejskal equation for (a) $\left[\mathrm{H}_{3} \mathrm{O}^{+} \cdot \mathrm{Dh}_{18 \mathrm{C} 6}\right] \mathrm{Tf} \mathrm{f}_{2} \mathrm{~N}$ at $70{ }^{\circ} \mathrm{C}$, (b) $\left[\mathrm{H}_{3} \mathrm{O}^{+} \cdot \mathrm{B} 18 \mathrm{C} 6\right] \mathrm{Tf}_{2} \mathrm{~N}$ at $75^{\circ} \mathrm{C}$, (c) $\left[\mathrm{H}_{3} \mathrm{O}^{+} \cdot \mathrm{G} 5\right] \mathrm{Tf}_{2} \mathrm{~N}$ at $25^{\circ} \mathrm{C}$, and (d) $\left[\mathrm{H}_{3} \mathrm{O}^{+} \cdot 18 \mathrm{C} 6\right] \mathrm{Tf}_{2} \mathrm{~N}$ at $75{ }^{\circ} \mathrm{C}$ (ref. 21): ligand (red circles) and $\mathrm{H}_{3} \mathrm{O}^{+}$(black circles). 
Table 4 Diffusion coefficients of $\mathrm{H}_{3} \mathrm{O}^{+}$and ligand for hydronium solvate ILs

\begin{tabular}{ccccc}
\hline compound & $\begin{array}{c}\text { Temp. } \\
{\left[{ }^{\circ} \mathrm{C}\right]}\end{array}$ & $\begin{array}{c}D_{\mathrm{H}_{3} \mathrm{O}^{+}} \\
{\left[10^{-7} \mathrm{~cm}^{2} \mathrm{~s}^{-1}\right]}\end{array}$ & $\begin{array}{c}D_{\text {ligand }} \\
{\left[10^{-7} \mathrm{~cm}^{2} \mathrm{~s}^{-1}\right]}\end{array}$ & $D_{\mathrm{H}_{3} \mathrm{O}^{+} /} D_{\text {ligand }}$ \\
\hline$\left[\mathrm{H}_{3} \mathrm{O}^{+} \cdot \mathrm{Dh} 18 \mathrm{C} 6\right] \mathrm{Tf}_{2} \mathrm{~N}$ & 70 & 0.56 & 0.21 & 2.7 \\
{$\left[\mathrm{H}_{3} \mathrm{O}^{+} \cdot \mathrm{B} 18 \mathrm{C} 6\right] \mathrm{Tf}_{2} \mathrm{~N}$} & 75 & 1.1 & 0.69 & 1.6 \\
{$\left[\mathrm{H}_{3} \mathrm{O}^{+} \cdot \mathrm{G} 5\right] \mathrm{Tf}_{2} \mathrm{~N}$} & 25 & 1.8 & 2.1 & 0.88 \\
${ }^{\mathrm{a}}\left[\mathrm{H}_{3} \mathrm{O}^{+} \cdot 18 \mathrm{C} 6\right] \mathrm{Tf}_{2} \mathrm{~N}$ & 75 & 3.6 & 2.4 & 1.5 \\
\hline
\end{tabular}

${ }^{\text {aData for }}\left[\mathrm{H}_{3} \mathrm{O}^{+} \cdot 18 \mathrm{C} 6\right] \mathrm{Tf}_{2} \mathrm{~N}$ are from ref. 21.

water in hydronium solvate ILs assists the cooperative proton relay. It is also notable that the activation energy for ionic conductivity is smaller than that for viscosity, not only in $\left[\mathrm{H}_{3} \mathrm{O}^{+} \cdot\right.$ Dh18C6] $\mathrm{Tf}_{2} \mathrm{~N}$ and $\left[\mathrm{H}_{3} \mathrm{O}^{+} \cdot \mathrm{B} 18 \mathrm{C} 6\right] \mathrm{Tf}_{2} \mathrm{~N}$ but also in $\left[\mathrm{H}_{3} \mathrm{O}^{+} \cdot \mathrm{G}_{5}\right] \mathrm{Tf}_{2} \mathrm{~N}$.

To discuss the difference of proton conduction between cyclicether-based hydronium solvate ILs and acyclic one from a structural viewpoint, graphical representations of the equilibrium geometry of the most stable conformers of $\left[\mathrm{H}_{3} \mathrm{O}^{+} \cdot 18 \mathrm{C} 6\right]$ and $\left[\mathrm{H}_{3} \mathrm{O}^{+} \cdot \mathrm{G} 5\right]$ are displayed in Figs. 6a and b, respectively. In the former case, every other oxygen atom of $18 \mathrm{C} 6$ coordinates to the $\mathrm{H}_{3} \mathrm{O}^{+}$, forming highly symmetric coordination via three equivalent hydrogen bonds, which

(a)
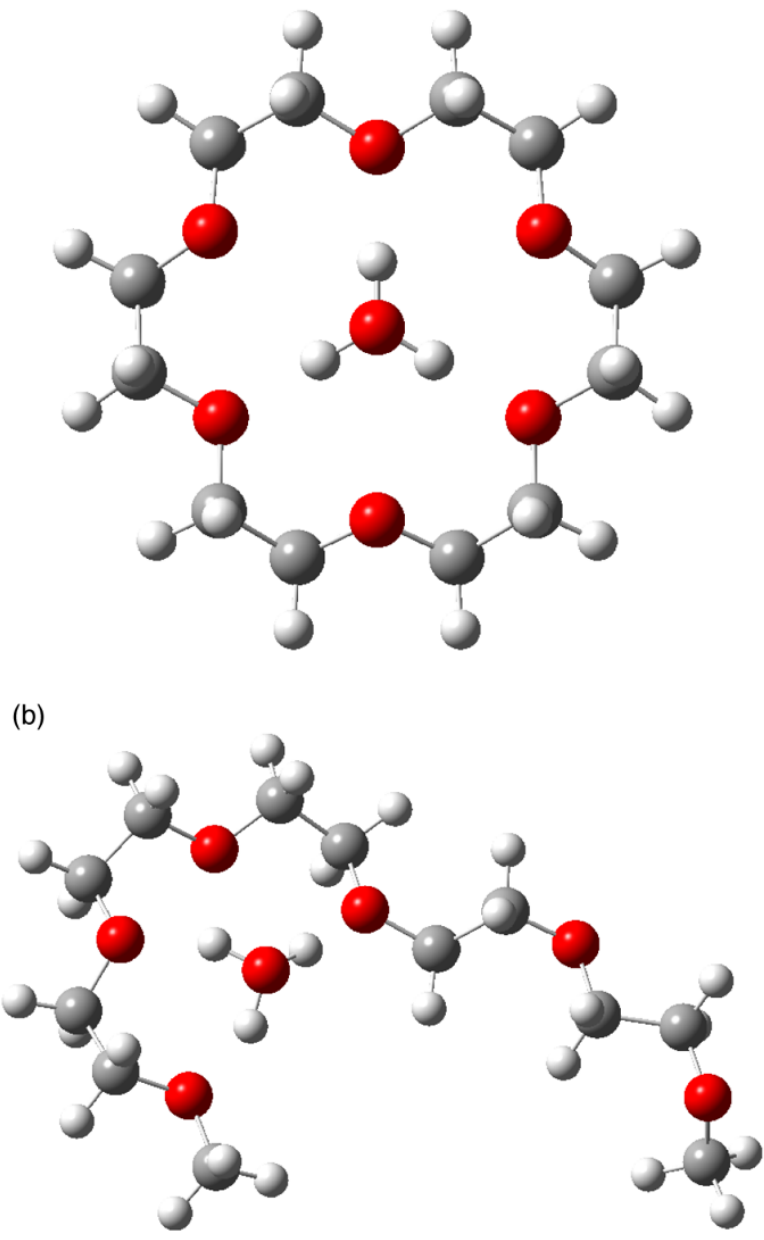

Fig. 6. Graphical representation of the equilibrium geometry of the most stable conformers of (a) $18 \mathrm{C} 6$ complexes with $\mathrm{H}_{3} \mathrm{O}^{+}$ (B3LYP/6-311+G** level) and (b) $\mathrm{G} 5$ complexes with $\mathrm{H}_{3} \mathrm{O}^{+}$ (B3LYP/6-311+G** level): oxygens in red, carbons in gray, and hydrogens in white. agrees with some pioneering works, ${ }^{36-38}$ and so do those of both Dh18C6 and B18C6 (Figure S1, S2). In the latter case, G5 does not wrap around the $\mathrm{H}_{3} \mathrm{O}^{+}$cation completely, and the first to fourth of the six oxygen atoms of $\mathrm{G} 5$ participate in coordination to the $\mathrm{H}_{3} \mathrm{O}^{+}$. A $\left[\mathrm{H}_{3} \mathrm{O}^{+} \cdot \mathrm{G} 5\right]$ complex does not form an 18C6-like coordination geometry but instead forms an asymmetric structure. These discussions are supported by the fact that $\left[\mathrm{H}_{3} \mathrm{O}^{+} \cdot \mathrm{G} 5\right] \mathrm{Tf}_{2} \mathrm{~N}$ undergoes glass transition at $-90{ }^{\circ} \mathrm{C}$ while $\left[\mathrm{H}_{3} \mathrm{O}^{+} \cdot 18 \mathrm{C} 6\right] \mathrm{Tf}_{2} \mathrm{~N}$ crystalizes at $66-$ $68{ }^{\circ} \mathrm{C}$, although the molar weights of the two compounds are almost the same. Consequently, the degree of structural freedom of G5 is larger than that of the 18C6-based ligand because G5 is an acyclic, open-chain ligand.

In common protic ILs, reorientation of a proton acceptor is required for the fast proton transfer. ${ }^{39}$ Although the proton transfer mechanism differs between hydronium solvate ILs and common protic ILs -in that the former does not include excess neutral molecules that can help proton relay-, we consider that ligand

(a)

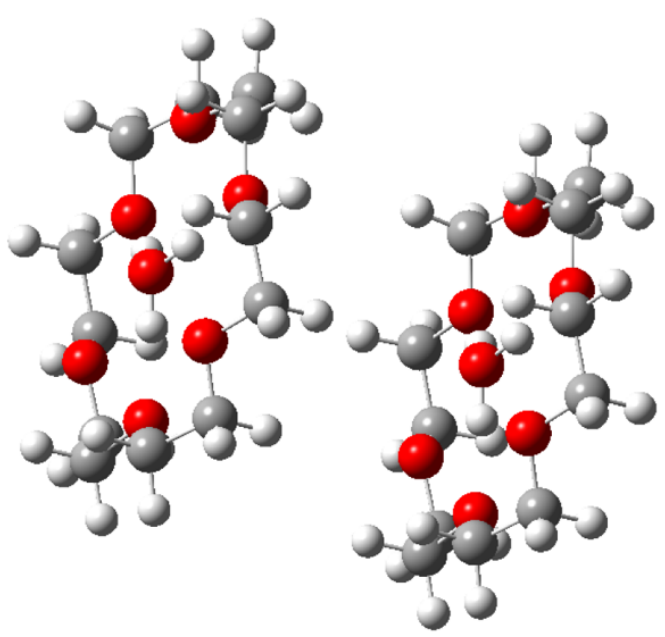

(b)

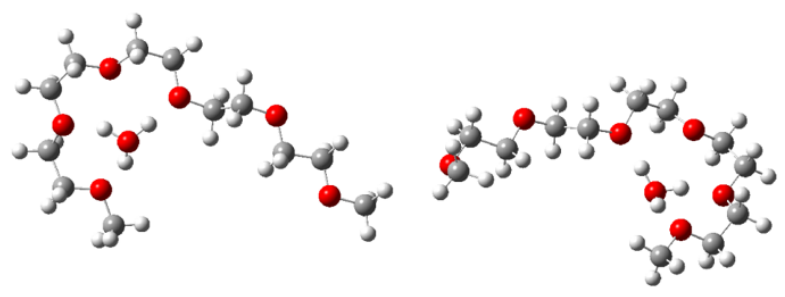

Fig. 7. Graphical representation of the equilibrium geometry of the most stable conformers of (a) two $\left[\mathrm{H}_{3} \mathrm{O}^{+} \cdot 18 \mathrm{C} 6\right]$ cations and (b) two $\left[\mathrm{H}_{3} \mathrm{O}^{+} \cdot \mathrm{G} 5\right]$ cations (B3LYP/6-311+G** level): oxygens in red, carbons in gray, and hydrogens in white. 
reorientation is also needed for the fast proton conduction in hydronium solvate ILs. In fact, the optimized structure of two solvate cations, which is performed to investigate their degree of orientation, clearly show that the pairs of $\left[\mathrm{H}_{3} \mathrm{O}^{+} \cdot 18 \mathrm{C} 6\right]$ face each other (Figure $7 \mathrm{a}$ ), while two $\left[\mathrm{H}_{3} \mathrm{O}^{+} \cdot \mathrm{G} 5\right]$ do not (Fig. 7b). In the system like biological ion channel, where ions pass through the specific path, ligands are needed to line up in parallel. A solid system where crown ether stacks are known as an artificial analogue of such ion channel. ${ }^{40}$ In the hydronium solvate ILs, where solvate cations and anions move relative to each other, the solvate cations will not stay and stack at specific area. Nonetheless, whether the ligands face each other frequently or not, i.e. whether the ligand reorientation occurs frequently, is important for the proton conduction. That is, the results shown in Fig. 7 strongly indicate the large difference in the probabilities of ligand reorientation for the crown ether and the glyme solvates. In $\left[\mathrm{H}_{3} \mathrm{O}^{+} \cdot \mathrm{G}_{5}\right] \mathrm{Tf}_{2} \mathrm{~N}$, fast proton conduction has not been found, evidencing that states in which two $\left[\mathrm{H}_{3} \mathrm{O}^{+} \cdot \mathrm{G} 5\right]$ face each other are infrequent. Certainly, the open G5 ligand is more flexible than the closed 18C6-based ligands. However, G5 cannot maintain the specific states of ligand orientation required for the fast proton conduction due to its high flexibility, which may suppress fast proton conduction. In contrast, the ligand reorientation occurs frequently for the 18C6-based ligands owing to its rigidity. As a result, conduction paths are available for a cooperative proton relay and fast proton conduction takes place.

Here we further discuss why such different proton conduction is observed in the cyclic- and acyclic-ligand-based hydronium solvate ILs. Crown ethers show amphiphilicity because of the hydrophobic $\mathrm{CH}_{2} \mathrm{CH}_{2}-$ groups and the hydrophilic inherent ether oxygens. The ether oxygens are well situated to coordinate with a cation located at the interior of the ring, whereas the exterior of the ring is hydrophobic. The cyclic molecules can divide hydrophilic area and hydrophobic area due to its closed nature. Therefore, the fast proton conduction appears in cyclic-ligand-based hydronium solvate ILs. Especially, Dh18C6 shows more exterior hydrophobicity than 18C6 owing to two cyclohexane moieties, resulting larger ratio of diffusion coefficients of $\mathrm{H}_{3} \mathrm{O}^{+}$and ligand in $\left[\mathrm{H}_{3} \mathrm{O}^{+} \cdot\right.$ Dh18C6]Tf $\mathrm{T}_{2} \mathrm{~N}$ than in $\left[\mathrm{H}_{3} \mathrm{O}^{+} \cdot 18 \mathrm{C} 6\right] \mathrm{Tf}_{2} \mathrm{~N}$. Apparently, B18C6 also shows exterior hydrophobicity compared to 18C6. Benzene ring, however, is known not only as a hydrophobic solute but also as a hydrogen bond acceptor. ${ }^{41}$ As a result, the ratio of diffusion coefficients of $\mathrm{H}_{3} \mathrm{O}^{+}$and ligand is almost the same in $\left[\mathrm{H}_{3} \mathrm{O}^{+} \cdot \mathrm{B} 18 \mathrm{C} 6\right] \mathrm{Tf}_{2} \mathrm{~N}$ and in $\left[\mathrm{H}_{3} \mathrm{O}^{+} \cdot 18 \mathrm{C} 6\right] \mathrm{Tf}_{2} \mathrm{~N}$. On the other hand, glyme molecules can also show both hydrophobicity and hydrophilicity. The two properties, however, cannot completely be interior/exterior for such open-chain and flexible molecules. Thus, it is the closed nature of crown ether or "partitioned amphiphilicity" that gives conduction paths for the cooperative proton relay. In $\left[\mathrm{H}_{3} \mathrm{O}^{+} \cdot \mathrm{G} 5\right] \mathrm{Tf}_{2} \mathrm{~N}$, such conduction paths for cooperative proton relay are not available. It may be notable that hydronium solvate ILs may relate to the ionics in biological ion channels. By utilizing crown ethers, artificial ion channels have widely been studied, ${ }^{40,42-47}$ where hydrophilic ion channel in hydrophobic lipid bilayer is mimicked. Although these studies focus on ion selectivity and ion transport, as far as we know, the effect of the partitioned amphiphilicity on the ionics by comparing the ligand structure has not been reported.
Consequently, the proton conduction of cyclic-ligand-based hydronium solvate ILs and that of acyclic counterpart are different. The DFT calculations show that the rigidity of $18 \mathrm{C} 6$ allows two $\left[\mathrm{H}_{3} \mathrm{O}^{+} \cdot 18 \mathrm{C} 6\right]$ cations to be parallel, implying small ligand reorientation, while two $\left[\mathrm{H}_{3} \mathrm{O}^{+} \cdot \mathrm{G} 5\right]$ cations are not. Therefore, the fast proton conduction only appears in cyclic-ligand-based hydronium solvate ILs. Additionally, since the conduction carrier is protons of $\mathrm{H}_{3} \mathrm{O}^{+}$or $\mathrm{H}_{3} \mathrm{O}^{+}$itself in hydronium solvate ILs, the hydrophilic area of ligand plays a role as proton acceptor. The hydrophilic and hydrophobic area of cyclic ligand can be divided owing to its closed nature, while those of acyclic one cannot because it is open chain. Therefore, we propose that the topology of the ethereal ligands is a clue for the proton conduction of hydronium solvate ILs.

\section{Conclusions}

The dependence of ligand shape on the proton conduction in hydronium solvate ILs was studied. While protons of $\mathrm{H}_{3} \mathrm{O}^{+}$move faster than the cyclic 18C6-based ligands, such fast proton conduction was not observed in the case of acyclic G5 ligands. Consequently, whether $\mathrm{H}_{3} \mathrm{O}^{+}$ion is coordinated by cyclic or acyclic ligands - in other words, whether $\mathrm{H}_{3} \mathrm{O}^{+}$wears a "crown" or "tiara" - is a key factor for proton conduction in hydronium solvate ILs, and the "coronation" or the crown-ether coordination matters. These findings should reflect the topological difference of the ethereal ligands. For further studies, molecular dynamics simulations for these hydronium solvate ILs, which would detect temporal ion channels in liquids, are of special interest. Our findings can provide guidelines to design new electrolyte systems for fuel cells and artificial ion channels for biological cells.

\section{Conflicts of interest}

There are no conflicts to declare.

\section{Acknowledgements}

The authors acknowledge Prof. Yasuhiro Umebayashi (Niigata University) for his support with the DFT calculations. This work was supported financially by Grants-in-Aid for Grants-in-Aid for Scientific Research (S) (No. 20H05663: K. M.), Scientific Research (B) (No. 19H02490: A. K.) and Grant-in-Aid for Challenging Research (Exploratory) (No. 19K22056: A. K.) from the Japan Society for the Promotion of Science. A. K. also thanks the Joint Usage/Research Program on Zero-Emission Energy Research, Institute of Advanced Energy, Kyoto University (ZE31A-1 and ZE2020A-09).

\section{References}

1 T. Welton, Chem. Rev., 1999, 99, 2071-2083.

2 K. Fujita, K. Murata, M. Masuda, N. Nakamura, and H. Ohno, RSC Adv., 2012, 2, 4018-4030.

3 T. L. Greaves and C. J. Drummond, Chem. Rev., 2015, 115, 11379-11448 
4 P. A. Hunt, C. R. Ashworth, and R. P. Matthews, Chem. Soc. Rev., 2015, 44, 1257-1288.

5 M. Armand, F. Endres, D. R. MacFarlane, H. Ohno, and B. Scrosati, Nat. Mater., 2009, 8, 621-629.

6 A. S. Amarasekara, Chem. Rev., 2016, 116, 6133-6183.

7 C. A. Angell, Y. Ansari, and Z. Zhao, Faraday Discuss., 2012, 154, 9-27.

8 A. Kitada, S. Takeoka, K. Kintsu, K. Fukami, M. Saimura, T. Nagata, M. Katahira, and K. Murase, J. Electrochem. Soc., 2018, 165, H121-H127.

9 G. S. Heo and R. A. Bartsch, J. Org. Chem.,1982, 47, 35573559.

10 R. Chênevert, A. Rodrigue, P. Beauchesne, and R. Savoie, Can. J. Chem., 1984, 62, 2293-2298.

11 R. Chênevert and A. Rodrique, J. Chem. Educ., 1984, 61, 465466.

12 R. Chênevert, D. Chamberland, M. Simard, and F. Brisse, Can. J. Chem., 1989, 67, 32-36.

13 T. Yasuda and M. Watanabe, MRS Bull., 2013, 38, 560-566.

14 J. Gao, G. Wang, Z. Wang, Y. Wang, J. Liu, W. Liu, and Z. Zou, J. Mater. Chem. A, 2014, 2, 19275-19281.

15 C. Ke, J. Li, X. Li, Z. Shao, and B. Yi, RSC $A d v ., 2012,2$, 8953-8956.

16 C. Chiappe and S. Rajamani, Eur. J. Org. Chem., 2011, 2011, $5517-5539$

17 R. Skoda-Földes, Molecules, 2014, 19, 8840-8884.

18 Z. Duan, Y. Gu, J. Zhang, L. Zhu, and Y. Deng, J. Mol. Catal. A: Chem., 2006, 250, 163-168.

19 Y. L. Geng, L. Y. Hu, X. Q. Zhao, H. L. An, and Y. J. Wang, Chin. J. Chem. Eng., 2009, 17, 756-760.

20 H. Xing, T. Wang, Z. Zhou, and Y. Dai, J. Mol. Catal. A: Chem., 2007, 264, 53-59.

21 A. Kitada, K. Kintsu, S. Takeoka, K. Fukami, M. Saimura, T. Nagata, M. Katahira, and K. Murase, J. Electrochem. Soc., 2018, 165, H496-H499.

22 K. Yoshida, M. Nakamura, Y. Kazue, N. Tachikawa, S. Tsuzuki, S. Seki, K. Dokko, and M. Watanabe, J. Am. Chem. Soc., 2011, 133, 13121-13129.

23 M. A. B. H. Susan, A. Noda, S. Mitsushima, and M. Watanabe, Chem. Commun., 2003, 938-939.

24 A. Noda, M. A. B. H. Susan, K. Kudo, S. Mitsushima, K. Hayamizu, and M. Watanabe, J. Phys. Chem. B, 2003, 107, 4024-4033.

25 H. Doi, X. Song, B. Minofar, R. Kanzaki, T. Takamuku, and Y. Umebayashi, Chem. Eur. J., 2013, 19, 11522-11526.

26 K. Kawata, A. Kitada, N. Tsuchida, M. Saimura, T. Nagata, M. Katahira, K. Fukami, and K. Murase, J. Electrochem. Soc., 2020, 167, 046508.

27 X. Wang, C. Bommier, Z. Jian, Z. Li, R. S. Chandrabose, I. A. Rodríguez-Pérez, P. A. Greaney, and X. Ji, Angew. Chem. Int. Ed., 2017, 56, 2909-2913.

28 Y. Zhu, X. Yang, and X. Zhang, Angew. Chem. Int. Ed., 2017, 56, 6378-6380.

29 P. C. Junk, New J. Chem., 2008, 32, 762-773.

30 E. O. Stejskal and J. E. Tanner, J. Chem. Phys., 1965, 42, 288292.

31 M. J. Frisch, G. W. Trucks, H. B. Schlegel, G. E. Scuseria, M. A. Robb, J. R. Cheeseman, G. Scalmani, V. Barone, G. A. Petersson, H. Nakatsuji, X. Li, M. Caricato, A. V. Marenich, J. Bloino, B. G. Janesko, R. Gomperts, B. Mennucci, H. P. Hratchian, J. V. Ortiz, A. F. Izmaylov, J. L. Sonnenberg, D. Williams-Young, F. Ding, F. Lipparini, F. Egidi, J. Goings, B. Peng, A. Petrone, T. Henderson, D. Ranasinghe, V. G. Zakrzewski, J. Gao, N. Rega, G. Zheng, W. Liang, M. Hada, M. Ehara, K. Toyota, R. Fukuda, J. Hasegawa, M. Ishida, T. Nakajima, Y. Honda, O. Kitao, H. Nakai, T. Vreven, K. Throssell, J. A. Montgomery, Jr., J. E. Peralta, F. Ogliaro, M. J. Bearpark, J. J. Heyd, E. N. Brothers, K. N. Kudin, V. N.
Staroverov, T. A. Keith, R. Kobayashi, J. Normand, K. Raghavachari, A. P. Rendell, J. C. Burant, S. S. Iyengar, J. Tomasi, M. Cossi, J. M. Millam, M. Klene, C. Adamo, R. Cammi, J. W. Ochterski, R. L. Martin, K. Morokuma, O. Farkas, J. B. Foresman, D. J. Fox, Gaussian 16, Revision A.03, Gaussian Inc., Wallingford CT, 2016.

32 C. Daguenent, P. J. Dyson, I. Krossing, A. Oleinikova, J. Slattery, C. Wakai, and H. Weingärtner, J. Phys. Chem. B, 2006, 110, 12682-12688.

33 T. Mandai, K. Yoshida, K. Ueno, K. Dokko, and M. Watanabe, Phys. Chem. Chem. Phys., 2014, 16, 8761-8772.

34 A. Kitada, D. Ishikawa, K. Fukami, and K. Murase, J. Electrochem. Soc., 2017, 164, H5119-H5123.

35 K. Ueno, K. Yoshida, M. Tsuchiya, N. Tachikawa, K. Dokko, and M. Watanabe, J. Phys. Chem. B, 2012, 116, 11323-11331.

36 M. Bühl and G. Wipff, J. Am. Chem. Soc., 2002, 124, 44734480.

37 A. Varnek, G. Wipff, A. Famulari, M. Raimondi, T. Vorob'eva, and E. Stoyanov, J. Chem. Soc., Perkin. Trans. 2, 2002, 887893.

38 M. Bühl, R. Ludwig, R. Schurhammer, and G. Wipff, J. Phys. Chem. A, 2004, 108, 11463-11468.

39 M. L. Hoarfrost, M. Tyagi, R. A. Segalman, and J. A. Reimer, J. Phys. Chem. B, 2012, 116, 8201-8209.

40 K. M. Fromm and R. D. Bergougnant, Solid State Sci., 2007, 9, 580-587.

41 T. R. Raschke and M. Levitt, J. Phys. Chem. B, 2004, 108, 13492-13500.

42 V. E. Carmichael, P. J. Dutton, T. M. Fyles, T. D. James, J. A. Swan, and M. Zojaji, J. Am. Chem. Soc., 1989, 111, 767-769.

43 M. F. M. Roks and R. J. M. Nolte, Macromolecules, 1992, 25 , 5398-5407.

44 A. Cazacu, C. Tong, A. van der Lee, T. M. Fyles, and M. Barboiu, J. Am. Chem. Soc., 2006, 128, 9541-9548.

45 T. Liu, C. Bao, H. Wang, L. Fei, R. Yang, Y. Long, and L. Zhu, New J. Chem., 2014, 38, 3507-3513.

46 T. M. Fyles, T. D. James, and K. C. Kaye, J. Am. Chem. Soc., 1993, 115, 12315-12321.

47 Z. Sun, M. Barboiu, Y. -M. Legrand, E. Petit, and A. Rotaru, Angew. Chem., 2015, 127, 14681-14685. 
Electronic Supplementary Information (ESI)

\section{Proton conduction in hydronium solvate ionic liquids affected by ligand shape}

Kio KAWATA, ${ }^{\mathrm{a}}$ Atsushi KITADA, ${ }^{\mathrm{a}, *}$ Naoki TSUCHIDA, ${ }^{\mathrm{a}}$ Masayuki SAIMURA, ${ }^{\mathrm{b}}$

Takashi NAGATA, ${ }^{\mathrm{b}}$ Masato KATAHIRA, ${ }^{\mathrm{b}}$ Kazuhiro FUKAMI, ${ }^{\mathrm{a}}$ and Kuniaki MURASE ${ }^{\mathrm{a}}$

${ }^{a}$ Department of Materials Science and Engineering, Kyoto University, Sakyo-ku, Kyoto

606-8501, Japan

${ }^{\mathrm{b}}$ Institute of Advanced Energy, Kyoto University, Gokasho, Uji, Kyoto 611-0011, Japan

*Corresponding author: kitada.atsushi.3r@kyoto-u.ac.jp 
Table S1. Ionic conductivities and viscosities of $\left[\mathrm{H}_{3} \mathrm{O}^{+} \cdot \mathrm{Dh} 18 \mathrm{C} 6\right] \mathrm{Tf}_{2} \mathrm{~N}$ at various temperatures.

\begin{tabular}{|c|c|c|}
\hline Temperature $\left({ }^{\circ} \mathrm{C}\right)$ & Conductivity $\left(\mathrm{mS} \mathrm{cm}^{-1}\right)$ & Viscosity $(\mathrm{mPa})$ \\
\hline 50 & 0.15 & 677 \\
\hline 55 & 0.23 & 440 \\
\hline 60 & 0.32 & 300 \\
\hline 65 & 0.44 & 212 \\
\hline 70 & 0.58 & 155 \\
\hline 75 & 0.75 & 117 \\
\hline 80 & 0.95 & 90.0 \\
\hline 85 & 1.2 & 70.8 \\
\hline 90 & 1.4 & 56.7 \\
\hline
\end{tabular}


Table S2. Ionic conductivities and viscosities of $\left[\mathrm{H}_{3} \mathrm{O}^{+} \cdot \mathrm{B} 18 \mathrm{C} 6\right] \mathrm{Tf}_{2} \mathrm{~N}$ at various temperatures.

\begin{tabular}{|c|c|c|}
\hline Temperature $\left({ }^{\circ} \mathrm{C}\right)$ & Conductivity $\left(\mathrm{mS} \mathrm{cm}^{-1}\right)$ & Viscosity $(\mathrm{mPa} \mathrm{s})$ \\
\hline 60 & 0.37 & 263 \\
\hline 65 & 0.50 & 190 \\
\hline 70 & 0.65 & 140 \\
\hline 75 & 0.85 & 107 \\
\hline 80 & 1.1 & 83.1 \\
\hline 85 & 1.3 & 65.7 \\
\hline
\end{tabular}


Table S3. Ionic conductivities and viscosities of $\left[\mathrm{H}_{3} \mathrm{O}^{+} \cdot \mathrm{G} 5\right] \mathrm{Tf}_{2} \mathrm{~N}$ at various temperatures.

\begin{tabular}{|c|c|c|}
\hline Temperature $\left({ }^{\circ} \mathrm{C}\right)$ & Conductivity $\left(\mathrm{mS} \mathrm{cm}^{-1}\right)$ & Viscosity $(\mathrm{mPa} \mathrm{s})$ \\
\hline 5 & 0.83 & 143 \\
\hline 15 & 1.4 & 81.0 \\
\hline 25 & 2.2 & 50.2 \\
\hline 35 & 3.3 & 33.5 \\
\hline 45 & 4.6 & 23.4 \\
\hline
\end{tabular}




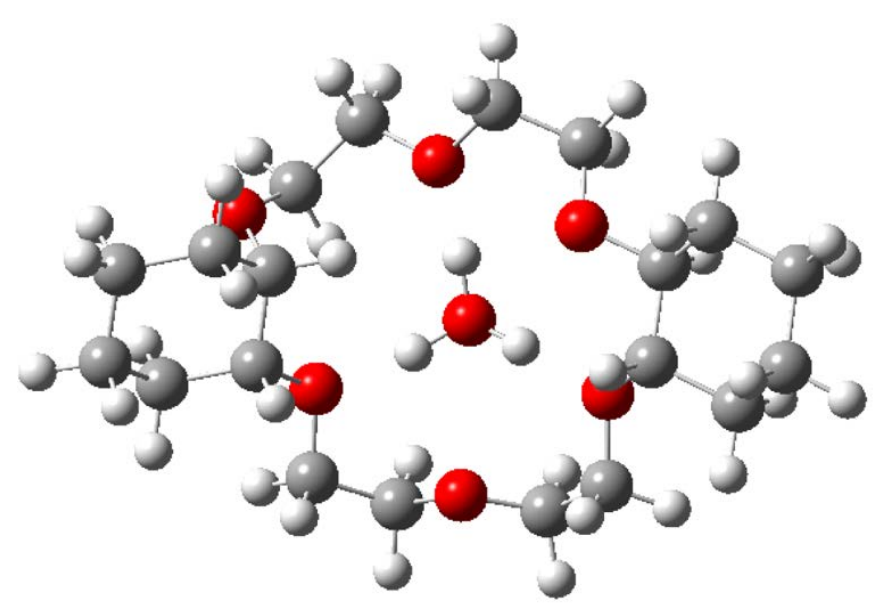

Fig. S1 Graphical representation of the equilibrium geometry of the most stable conformers of Dh18C6 complexes with $\mathrm{H}_{3} \mathrm{O}^{+}\left(\mathrm{B} 3 \mathrm{LYP} / 6-311+\mathrm{G}^{* *}\right.$ level): oxygens in red, carbons in gray, and hydrogens in white.

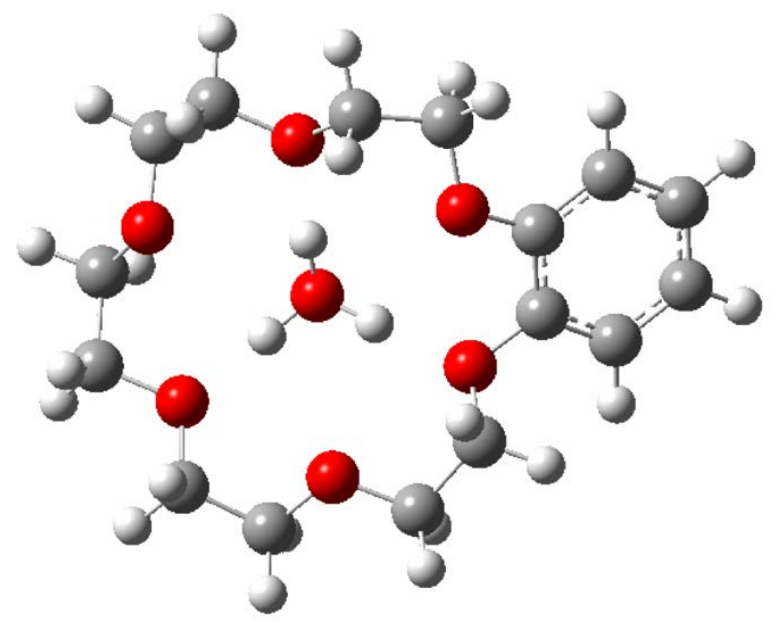

Fig. S2 Graphical representation of the equilibrium geometry of the most stable conformers of B18C6 complexes with $\mathrm{H}_{3} \mathrm{O}^{+}$(B3LYP/6-311+G** level): oxygens in red, carbons in gray, and hydrogens in white. 